\title{
Law's Transformative Power: Ideology, Utopia, and Donald Trump
}

\author{
Stacy Douglas
}

\section{Introduction}

The late American Supreme Court Justice Antonin Scalia was a famed 'originalist'. The term, familiar to legal scholars in the United States, refers to an individual who believes that the Constitution should not be interpreted over time to fit a changing social, political, and economic context, but rather that it should always be read as it was written and signed in 1787. Although metaphors such as 'living' and 'growing' normally abound in discussions of constitutional documents, originalists like Scalia believe otherwise: 'The Constitution that I interpret and apply is not living but dead, or as I prefer to call it, enduring. It means today not what current society, much less the court, thinks it ought to mean, but what it meant when it was 
adopted.' ${ }^{1}$ Scalia's fidelity to the past and to an unchanging vision of the legal text, let alone his a-historical vision of American life, begs fascinating questions about law, temporality and symbolism. For the notoriously conservative judge, the text stands as an immutable directive, to which social and historical context matters not. The US Constitution is an unwavering set of commands and protections that echo steadily from the end of the American Revolution onwards. Interpretation, in this program, stems from authorial intent.

This attachment to authenticity - presumed as locatable in both the authors' intentions and the document's assumed unidimensional meaning - is hard for many to swallow. Indeed, it is not uncommon to hear scoffs amongst liberal audiences at what is assumed to be originalists' naiveté, and to feel a palpable disdain for a shallow thinking that refuses to consider historical context in juridical analyses. But this disposition is not isolated to Scalia and other worshippers of the drafters of so-called American democracy. Such loyalty to universally applied interpretive methods can also be found amongst liberal sceptics. Although deploying a different set of devices, the anti-originalist faction understands the Constitution according to its own creed, one that diminishes the authors' intentions and asserts the importance of a socially-situated lens in all adjudicational situations. In both cases, legal scholars, although with opposing positions on the role of social-determination, hold firmly to a

\footnotetext{
Antonin Scalia, “God's justice and ours”. First Things: A Journal of Religion, Culture and Public Life, 123, (2002): 17-21.
} 
belief in universally appropriate and applicable interpretation, authorised by their own convictions. And, in fact, the specificity of these methods may be much closer than anyone would care to admit.

This chapter investigates these competing claims by looking to the election of Donald J. Trump as the United States of America's $45^{\text {th }}$ President in November 2016 and his winning campaign promise to 'make America great again'. It seems that Trump's own nostalgia for 'originalism' both in his populist sloganeering, as well as his Supreme Court nomination to replace the late Scalia - have resonance with a large swath of the American public. While anti-Trump voters ridicule this nationalist sentimentality, its prevailing popularity cannot be denied and, as such, it is deserving of critical investigation. The question for legal scholars is how to understand the power of originalism and its place in theories of transformation. How does the projection of an unmediated text or image of a 'world to return to', undergird these bold political claims?

It is key to remember, however, that such visions of change animate both originalists' and anti-originalists' imaginations. Indeed, both camps, despite their political divergences, often rely on symbolic projection in their philosophies of renewal. While Trump and his supporters use the image of an old (even if mythological) America, his opposition also deploys imagined visions of the future for inspiring and accelerating a world yet-to-come. In both cases, it is symbolic projection of a better world (with subjective content) that lies beneath the ideology. This chapter seeks to poke at this commonly shared visual strategy of transformation to ask whether or not there is 
something important at stake in identifying this commonality, and whether there is not something pernicious about the method (not simply the content) itself.

In order to pursue these questions, the chapter explores a popular theory of legal transformation that depends on visual cues as articulated by philosopher Drucilla Cornell. Cornell, who draws on Immanuel Kant in constructing her theory, is wedded to the role of 'moral images of freedom' in creating positive change in the world. For her, it is such images that provide the space for imagined alternatives to oppressive and restrictive law and regulation; it is the imagination that is the source of freedom and, as such, must be protected. Below I trace the capacities and function of the image in Cornell, as it comes from Kant, to show precisely how and why it is so central for her. It is without doubt true that Cornell is an avowed leftist, deeply committed to creating a world that is more just and humane through this theory of transformation, as well as to ethical behaviour and political struggle. However, this chapter wonders at the common use of image and imagination and their symbolic projections for both left- and right-leaning projects. Of course, one could say that it is not the method that is the problem, but the content. Indeed, nostalgic desire to return to an imagined past has long since been the subject of critique by anti-fascist theorists who have witnessed such desires transform into genocidal practices. To be sure, Cornell and others invested in the role of the symbolic are in no way perpetuating such myths.

In his influential text, The Political Unconscious, however, theorist Fredric Jameson suggests that the problem 
may indeed be the method and not the content. He asks readers to consider the social and historical context of cultural products. He suggests that tropes articulated in one text cannot be easily transposable to other social and historical times. This is because each product contains its own set of historically determined assumptions and codes that cannot be universalised. As such, Jameson asks after the frame or method of interpretation, not only the content, and is one voice that gives us pause when considering the transplantation of the Kantian technique of 'moral images of freedom' from the German philosopher's social and historical context in 1790, to the present day.

I contend that, ultimately, Cornell and Jameson give us varying but competing theories of transformation that rely on symbolic projection and utopian thinking, both of which are illuminating. Especially helpful about their work is that, when juxtaposed, the futility of attempting to pin the problem on merely the content or merely the form is revealed for the empty exercise that it is. This insight is helpful in contemplating both the resonance of contemporary originalism and Trump's populist revival of its derivation via his claim to return America to its lost grandeur. Ultimately, this political development must be understood for both its form and content, and for what it says about the world we live in and the worlds we imagine we want to live in.

\section{Cornell \& the Image}

Drucilla Cornell builds on Virginia Woolf's concept of 'a room of one's own' when she employs the 'imaginary 
domain'. For Cornell, the imaginary domain 'allows the imagination to roam freely in the safety provided by the acceptance of play as crucial to sexual pleasure.2 In other words, the imaginary domain is the psychic space that should be afforded - and guaranteed - to individuals in order for them to attain their somatic and sexual freedom. Cornell is deeply attached to the role of the imagination in her theory of transformation for two reasons. Firstly, because the imagination is where our 'most primordial sexual formations' take shape (both in ourselves and in the images that others have of us). Secondly, the imagination plays a central role in the acting out and performance of our 'sexuate being' as it is moulded and re-moulded throughout our lives. In short, for Cornell, the imagination links to the 'possible field of play within sexual difference' and is, therefore, a key site of individual and collective freedom, and must be defended as a matter of justice. ${ }^{3}$ In this way, Cornell is deeply Kantian.

Cornell draws on Kant's last book, Critique of Judgment, in her lionisation of the power of the imagination. Kant's third treatise differs from the previous two in that he no longer focuses on the role of rationality but on the capacity of the imagination. Or that, put better, in the arena of aesthetic judgement, reason is shown to be a deficient tool on its own; judgement requires the imagination. ${ }^{4}$ Kant

2 Drucilla Cornell, Moral Images of Freedom: A Future for Critical Theory (New York: Rowman and Littlefield Publishers Inc., 2008), 13.

3 Ibid., 15

4 Immanuel Kant Critique of the Power of Judgment. (Cambridge: Cambridge University Press, 2000), 29; Cornell, Moral Images of Freedom: A Future for Critical Theory, 29. 
contends that conceptualisation (i.e., the use of concepts) has no place in aesthetic judgement, and rather that the recognition of beauty comes from subjective feelings. In other words, we do not, Cornell says, know through learned categories that something is beautiful; we feel that something is beautiful: 'for Kant, the powerful role of an aesthetic idea is that it activates the spirit and so as to make these great ideas come alive, irreducible to empty abstraction. ${ }^{5}{ }^{6}$ But he does not stop there.

Kant further claims that these mere subjective feelings are not quite enough. Once beauty is observed, absent of or without the assistance of previous schematisation, it must be related to a more general or universalisable ideal of beauty that can transcend the merely subjective experience. According to Cornell, 'Kant calls us to form a universalisable ideal of beauty in each one of us as a guidepost for taste even as this ideal must be developed in each one of us independently.' Kant emphasises

5 Cornell, Moral Images of Freedom: A Future for Critical Theory, 14.

${ }^{6}$ For Kant, understanding and imagination must exist together in free play, therefore I do not mean to suggest that there is no role whatsoever for judgement, but rather that imagination in the determination of feeling plays a bigger role in Critique of Judgment than in the earlier texts: "while it is the imagination that produces the schemata that are to be recognised as exhibitions of what is thought in reflected concept, it falls to judgement to recognise the actual fit between apprehended particular and concept. In other words, judgement is required in order to be able to take what is exhibited by the imagination as instantiating what is thought in a concept", Henry E. Allison, Kant's Theory of Taste: A Reading of the Critique of Judgment. (Cambridge: Cambridge University Press, 2001), 47. See also Ian Ward, "A Kantian (Re)Turn: Aesthetics, Postmodernism and Law", Law and Critique 6, no. 2 (1995): 257-271, 258.

7 Cornell, Moral Images of Freedom: A Future for Critical Theory, 19. 
that this universalisable ideal cannot function as a set of rules (for that would create a set of categories for it to accord to, which he explicitly rejects), and that it can only be attained in a second step, after each individual develops their own subjective ideal of beauty. ${ }^{8}$ And yet there is a need to develop a communal ideal of beauty, what he refers to as the sensus communis. For Kant, the sensus communis means 'the ability to judge by mere feelings in the absence of any conceptual grounds, and to do so universally in principle. ${ }^{\prime}$ This universalisable ideal of beauty wards off entirely subjective aesthetic judgements, which Kant determines as 'interested' judgements, and ensures that these ideals are true judgements of taste. ${ }^{10}$ For Kant, aesthetic experience offers the possibility of getting out of one's self and one's own subjectivity by participating in the experience of judgement, which for him was necessarily outwardly focused, requiring communication and sense-making with others. ${ }^{11}$

But what does all of this have to do with Cornell's theory of transformation? Cornell contends that human imagination is necessary for conceptualising alternative possibilities. She draws on Kant's important distinction between actuality and potentiality to elucidate the reasoning behind her investment in aesthetic ideas. But in

${ }^{8}$ Kant, Critique of the Power of Judgment, 166-167; Cornell, Moral Images of Freedom: A Future for Critical Theory, 21.

9 Cristian Nae, "Communicability and Empathy: Sensus Communis and the Idea of the Sublime in Dialogical Aesthetics", Proceedings of the European Society for Aesthetics 2, (2010): 361-385, 373.

10 Ibid., 373.

11 Ward, "A Kantian (Re)Turn", 262. 
order to understand the distinction between actuality and potentiality, and the role of the image, Cornell contends that we must first understand the role of the 'schema' in Kant's work.

In his Critique of Pure Reason, Kant elucidates his theory of 'schematism' as he explains his theory on the transcendental faculty of judgement. Here Kant argues that schemas are necessary to make sense of the world; schemas provide the conditions for sense to take place. Significantly, this schema is not an 'image' per se, but rather a general way of conceiving of figures in space. ${ }^{12}$ Sabhajit Mishra explains that

a schema enables us to form an image of the concept but is not itself an image. An image is particular whereas a schema is universal. If we think of ' 1 ', ' 2 ', ' 3 ', ' 4 ', ' 5 ' we get an image of number 5 . But if we think of number in general by which we can form an image not only of number five but any number whatsoever, we have a schema and not an image ${ }^{13}$

For example, Kant contends that the conception of a dog can conjure up a general idea of a four-footed animal (schema) without pertaining to an exact empirical example of a dog that may exhibit particular features (an image). He claims that,

the image is a product of the empirical faculty of the productive imagination - the schema of sensuous

12 Immanuel Kant, Critique of Pure Reason (New York: Palgrave MacMillan 2003), 180-187.

13 Sabhajit Mishra, "Kant's Schematism of Categories", Indian Philosophical Quarterly 7, no. 4 (1980): 489-500, 492. 
conceptions (of figures in space, for example) is a product, and, as it were, a monogram of the pure imagination a priori, whereby and according to which images first become possible, which, however, can be connected with the conception only mediately by means of the schema which they indicate, and are in themselves never fully adequate to it. ${ }^{14}$

In other words, schemas assist in the production of concepts that then allow us to think and communicate; schemas mediate humans' knowledge of things. As Kant points out here, these schemas are never fully adequate to the thing, but merely provide a framework from which to build upon. These frameworks or schemas draw upon what Kant assumes are universalisable truths that most people experience:

an image cannot render the universality of a concept possible. It is the schema which does so. Since schema is a rule by which different images are constructed it can realise all the possibilities that a concept (e.g., that of a triangle) may have (whether it is right angled or obtuse angled). An image on the other hand, can realise only one of those possibilities. ${ }^{15}$

In her Lectures on Kant's Political Philosophy, Hannah Arendt explains the importance of Kant's philosophy of

14 Kant, Critique of Pure Reason, 183.

15 Mishra, Kant's Schematism of Categories, 492. Mishra summarises succinctly: " ...a schema is a universal procedure of producing objects i.e. images of different kinds. According to Kant, there are three things - concept, schema, and image. It is by means of schema that we get the image of the concept" (ibid., 492 (emphasis mine). However, there is some debate about this. For an explication of Kant's own murky distinctions between schema, concept, and image, especially regarding whether or not the schema is particular or universal, see ibid., 494-495. 
schematism for his ideas of communication and understanding:

What makes particulars communicable is (a) that in perceiving a particular we have in the back of our minds (or in the 'depths of our souls') a 'schema' whose 'shape' is characteristic of many such particulars and (b) that this schematic shape is in the back of the minds of many different people. These schematic shapes are products of the imagination although 'no scheme can ever be brought into any image whatsoever'. All single agreements or disagreements presuppose that we, who are many, agree, come together, on something that is one and the same for us all. ${ }^{16}$

Arendt's summary highlights the way in which Kant's schemas incline towards universalism. However, what both Kant's and Arendt's quotes above point to, is that his endorsement of universalism comes as a result of his prolonged attempt to explain how humans come to know the world. What Kant is explaining is what the empiricists of his time such as Locke and Hume failed to address - humans' increased capacity to move and think in the world as a result of transcendental schematic arrangements. ${ }^{17}$ To return to the example of the dog, schemas

${ }^{16}$ Hannah Arendt, Lectures on Kant's Political Philosophy (Chicago: University of Chicago Press 1982), 83.

17 For example, as Professor Daniel Robinson claims in his lectures on Kant's Critique of Pure Reason, when we wake up in the morning to find that our car will not start, we do not immediately think that the laws of the internal combustion have ceased to be in operation. Rather, we presume that our car, and our car only, is broken. We are inclined to think that there is something wrong with it, rather than assume the failure of the universe in some more general way. D.N. Robinson, "Just What is Kant's Project?" Lecture One on Kant's Critique of Pure Reason" (Faculty of Philosophy, Oxford University 2011): 35”. 
allow us to think with broad categories of meaning that, in turn, allow us to communicate to each other. These schemas in turn allow humans to make judgements in the world. Without such schemas, we cannot experience phenomena.

Cornell turns to the work of Ernst Cassirer for further elucidation of the power of imagination in her theory of transformation. Cassirer took up Kant's thought on schema, but made an important addition, according to Cornell. For Cassirer, as he elaborates in his four-volume text The Philosophy of Symbolic Forms, language itself is a schema. Moreover, not only does language, as a set of symbolic forms, allow us to understand the world; it also crucially allows us to conceive of alternative possibilities to the world as it is presented to us. In other words, language - as a schema - does not just make possible representation through concepts and images but also, and simultaneously, it 'abstract[s] from the reality which [it] seek[s] to represent'; ${ }^{18}$ language is 'a means to new knowledge and indeed allows us to disclose new worlds. ${ }^{19}$ Elaborating on Kant's 'as-if' of the imagination, Cassirer tells us that symbolism always allows for more than just simple representation of actuality; it serves a double-function of serving as a platform for the possibility of understanding, but also as a platform for revealing alternative possibilities of meaning. Cornell explicates Cassirer's thought by drawing on scientific hypothesis and political theory

18 Cornell, Moral Images of Freedom: A Future for Critical Theory, 14.

19 Ibid., 85. 
that turns on this 'as-if conjectural reasoning. ${ }^{20}$ Both experiments rely on the imaginative technique that allows humans to distinguish between actual and possible objects and is common practice in imagining alternative worlds. For example, 'Cassirer's analysis of Rousseau's famous state of nature defends this state of nature as an imagined object used by Rousseau to vivify what is wrong with the France of the Third Estate' (Cornell 2008, 90). For Rousseau, as for Trump and Cornell, it is the juxtaposition between what is and what could be that creates the platform for imagining alternatives and, thereby, creating change.

This distinction between actuality and possibility, made by Kant and emphasised by Cassirer, is key to Cornell's endorsement of 'moral images of freedom'. For Cornell, this philosophical insight is what authorises a belief in the power of symbolic projection and an attendant investment in imagining otherwise. It is what allows her to be optimistic about the future; for her, the only thing we can be certain of is that we do not know what the future holds. ${ }^{21}$ For some, this may sound like a descent into idealism, the worst kind of mind-over-matter thinking materialist Marxists have famously rejected. But Cornell is quick to point out that the distinction between symbolism and materialism is false and that it fails to recognise that materiality is also symbolic. ${ }^{22}$ For Cornell, drawing

20 Ibid., 89.

21 Ibid., 33.

${ }^{22}$ Cornell elaborates on Cassirer's rejection of the presumed dualism between symbolism and materialism: "All material reality is always grasped by human beings as always already symbolised. Capital, as 
deeply on Cassirer, all phenomena are inextricable from symbolic form. This does not mean that she believes all transformation will come from imagining otherwise. Indeed, she is clear that political struggle and ethical commitment (and she does not shy away from a long history of armed anti-colonial and proletarian struggle) are necessary for change. ${ }^{23}$ However, it is symbolic projection, which stems from the philosophy of Kant and Cassirer, that undergirds her commitment to the power of the imagination in changing the world. The question this text seeks to ask is whether such a theory of transformation is always, or universally, relevant and mobilisable.

\section{The Form of Ideology (Or an Introduction to Jameson)}

Cultural theorist Fredric Jameson famously argues that reading and criticism cannot take place in an historical vacuum. Rather, all writing and reading is contingent on the social and historical context in which it takes place: 'our readings of the past are vitally dependent on our experience of the present, and in particular on the structural peculiarities of what is sometimes called the société de consommation. ${ }^{24}$ So for Jameson, contemporary read-

a symbolic form of life, can only be replaced by another symbolic form of life. This is the significance of Cassirer's insight that there is no material and ideal dualism for human beings; our material forms of life are always also symbolic". Ibid.,90.

23 Cornell, Moral Images of Freedom: A Future for Critical Theory, 90.

24 The "société de consommation" is translated in English as "consumer society". Fredric Jameson, The Political Unconscious: Narrative as a Socially Symbolic Act. (London: Routledge, 1981), xi. 
ing and writing is deeply influenced by the categories of thinking and horizon of possibilities that correspond with the early twenty-first century and its emphasis on consumerism, and institutionalised liberal-capitalist democracy. But his critique is not limited to the contemporary moment - for him, the historical and social relevance of time and context is important no matter what epoch you are reading or writing in.

Jameson's insight has great import for intellectuals of all sorts. Through his historical analysis of cultural producers from Honoré de Balzac to Joseph Conrad, he demonstrates that the central themes and tropes of these works are historically contingent; they are not 'the result of purely philosophic choices or options in the void, but are objectively determined. ${ }^{25}$ He takes aim at any universalising theory of critique - whether it be psychoanalytic or a crude economical approach - and argues that each suppresses its own historical contingency. He claims that '...in its generic form, a specific narrative paradigm continues to emit its ideological signals long after its original content has become historically obsolete. ${ }^{26}$ Jameson insists then that we must always historicise the cultural products we read, as well as the interpretive devices we use contemporarily, to understand them not as objective, but as products of their time. ${ }^{27}$ In this way, Jameson does

25 Ibid., 96.

26 Ibid., 174.

27 Ibid., ix.

Importantly, Jameson is not suggesting that all cultural texts are simply products of class domination at any one particular time, nor that this is an accurate understanding of a traditional Marxist analysis. He critiques Marshall Sahlins on this point who, according to 
promote a universal theory of interpretation - historical analysis. ${ }^{28}$

Jameson's insight begs a question of Kant's, and by association Cornell's, theory of transformation. Can we say that symbolic projection works the same way across social and political context and throughout history? Does the power of the imagination in visualising change function similarly today as it did in 1790 ? Certainly, there have been many critiques of Kant's turn to subjective, and away from objective, experience in his third book. Notably, Hans-Georg Gadamer and Hannah Arendt claim that Kant's Critique of Judgment radically transforms his project from one of seeking out universal values to one of particularity. As Ian Ward explains,

By encouraging the pure subjectivity of individuality, and the total unrestricted 'free play of imagination and understanding', he [Kant] placed the supremacy of freedom above all else, and granted it its own powers of structure. The pure a priori principle existed in its most acutely and purely subjective form, and

Jameson, suggests as much. Jameson responds: "Sahlins is untroubled by the paradox that Marx himself reserved his most brilliant polemic onslaughts for the classical form taken by an instrumental theory of culture in his own time, namely utilitarianism". Jameson, The Political Unconscious, 272. For Jameson's further opposition to the hegemony of "materialist critique" (as the new German Ideology) see Robert, Kauffman, "Red Kant, or the Persistence of the Third 'Critique' in Adorno and Jameson”. Critical Inquiry 26, no. 4 (2000): 682-724, 705; and Hayden White, "Getting Out of History". Diacritics, 12 no. 3 (1982): 2-13, 4.

28 For other commentary on this seeming paradox and how Jameson gets around it, see Geoff Bennington, "Not Yet." Diacritics 12 (1982): 23-32, 24; White, "Getting Out of History", 5; and Jerry Aline Flieger, "The Prison-House of Ideology: Critic as Inmate". Diacritics 12. No 3. (1982): 47-56, 51. 
as Gadamer emphasised, Kant thus opened the door to ever more acute relativism in subsequent critical philosophy. ${ }^{29}$

But this criticism is not exactly that of Jameson's. Rather, Jameson emphasises that reading Kant today necessarily involves the transposal and projection of contemporary lenses of morality, politics, and other conceptual understandings. So while Kant's work, according to more acutely Marxist critics, takes after the Young Hegelians and their 'commitment to critical consciousness as the engine of history' up against the Marxist imperative that revolution is the engine of history, Jameson's insight is that, regardless, Kant's contributions cannot simply be translated from the late eighteenth century to today. ${ }^{30}$ To make such an interpretive leap is to perpetuate what he calls 'liberal ideologies' and 'their functional utility in the repression of the social and the historical, and in the perpetuation of some timeless and ahistorical view of human life and social relations. ${ }^{31}$ But does this mean that Jameson is saying that there is no room for the role of symbolic projection in transformative change? If so, how else does one so committed to the role of cultural production envision a project of transformation?

Jameson claims that these cultural products need to be read and re-written in a way that exposes their social and historical contingencies. For example, with regards

29 Ward, A Kantian (Re)Turn: Aesthetics, Postmodernism and Law, 262.

30 Kauffman, "Red Kant”, 692.

${ }^{31}$ Fredric Jameson, Leonard Green, Jonathan Culler and Richard Klein, eds., "Interview: Fredric Jameson". Diacritics 12 no. 3 (1982): 72-91, 72 . 
to psychoanalysis, Jameson explicates how its historical situation, rather than universal supposition, might be revealed: 'the conditions of possibility of psychoanalysis become visible, one would imagine, only when you begin to appreciate the extent of psychic fragmentation since the beginnings of capitalism, with its systematic quantification and rationalisation of experience, its instrumental reorganisation of the subject just as much as of the outside world. ${ }^{32}$ This is the dialectic element of his argument. However, such revelation cannot be experienced by a sole individual subject, because they too will always already be a product of their social and historical conditioning. Jameson compares the individual to the analysand, never fully able to reach pure lucidity of their unconscious. In order to reach such clarity of thought, what is needed is a painful confrontation with a transcendent force, external to individual consciousness, able to expose the historical reality in which the individuals find themselves. For Jameson this transcendental could come in the form of 'a collective unity - whether that of a particular class, the proletariat, or of its 'organ of consciousness', the revolutionary party. ${ }^{33}$ It is a painful confrontation because it is engaged in a 'decentering' or displacement of the centrality of the individual consciousness and an opening up to an 'unpleasant reflexivity.'

Jameson does not simply dismiss cultural products, even when they are formations of particular contexts,

\footnotetext{
32 Ibid., 47.

33 Jameson, The Political Unconscious, 273-274.

34 Ibid., 274.
} 
as merely 'ideological'. He productively finds that their hidden ideological element only has legs in so far as it is accompanied by allusions to utopian thinking. In this way, Jameson holds strongly to an advanced conception of agency, one that gives subjects credit for willingly and optimistically participating in their own management. Against the doctrine of mere 'false consciousness', and along with theorists such as Ernst Bloch, he claims that what is happening is not just

... inscribing the appropriate attitudes upon a blank slate, but must necessarily involve a complex strategy of rhetorical persuasion in which substantial incentives are offered for ideological adherence. We will say that such incentives ... are necessarily Utopian in nature. ${ }^{35}$

In other words, for Jameson, ideology is always combined with utopianism, and this is not necessarily a good or a bad thing. For him, we must not deny the 'co-existence of different functions' in a cultural product; ideology and utopian thinking can be divergent and yet occur together. ${ }^{36}$ But it is also key to note that for Jameson, utopianism is not necessarily only a product for the left or the right but is always a product of a yearning for collective unity; utopianism is not the formation of the collective per se but, rather, the images that animate its imagined togetherness. He claims that:

...even hegemonic or ruling-class culture and ideology are Utopian, not in spite of their instrumental

${ }^{35}$ Ibid., 278.

36 Jameson, The Political Unconscious, 279. 
function to secure and perpetuate class privilege and power, but rather precisely because that function is also in and of itself the affirmation of collective solidarity. ${ }^{37}$

But this does not mean he sees utopian thinking as a thoughtless or irrelevant strategy. He takes it up, especially in later work, as a key potential tool for imagining otherwise, not unlike Cornell's use of Kant's 'moral images of freedom. The key difference between the two strategies, however, is that where Cornell and Kant see their theory of transformation as universalisable, Jameson insists that all such imaginations are always a product of their social and political context. So utopian thinking itself, regardless of when or where it is conceived, will always 'reflect a specific class-historical standpoint or perspective. ${ }^{38} \mathrm{He}$ works against the universalising tendency to treat utopian thinking as if it can be free from such constraints, as if it can rise 'above all immediate determinations in some allembracing resolution of every imaginable evil and misery of our own fallen society and reality. ${ }^{39}$ And this contextual understanding of utopia is important because it is this context that provides the key to truly transformative change. Rather than merely imagining a better future, as in Cornell and Kant, he insists that the power of utopianthinking lies in its suffocation in the present moment. In other words, it is its failure that provides hope. Impotence

\footnotetext{
37 Ibid., 281.

38 Fredric Jameson, “The Politics of Utopia”. New Left Review no. 25 (2004): 35-54, 47.

39 Ibid.
} 
of the imagination in a system that seems impossible to change reveals the ideological context within which we live; it reminds us of the social and historical box we find our thinking confined by. Utopia

...is most authentic when we cannot imagine it. Its function lies not in helping us to imagine a better future but rather in demonstrating our utter incapacity to imagine such a future-our imprisonment in a non-utopian present without historicity or futurity-so as to reveal the ideological closure of the system in which we are somehow trapped and confined. ${ }^{40}$

Whereas Cornell uses Rousseau to expound on the transformative moment between imagining what is and what might be (or in a more Kantian formulation, what is and what ought to be), Jameson uses Rousseau's insights to emphasise the importance of the gap between understanding that the world can and is changing, but the system that organises it cannot; utopias occur in these times of frustration. ${ }^{41}$ In other words, it is not the positive possibility of the thinking that is the engine for change, but rather its negation; in the negation, the ideological context of the system is exposed. ${ }^{42}$ However, the potential for change is not impossible; transformation is a reality that can come about and be inspired by utopian thinking. Even though such visions are not yet realised, this does not mean that they are non-existent: 'utopias in fact come

\footnotetext{
40 Jameson, "The Politics of Utopia”, 46.

41 Ibid., 45.

42 Ibid., 50.
} 
to us as barely audible messages from a future that may never come into being. ${ }^{43}$

The power of Jameson's contributions comes from his contention that ideology and utopia cannot be separated. This reminds us that, when we think along with Kant, we do not only need to acknowledge the social and historical context that the German philosopher was writing within, but also that any critique of his work as merely 'ideological' must also observe the utopian elements of his work. The same follows with Cornell's theory of transformation. It is not that law is simply an instrument of class oppression but, on the other hand, utopian thinking cannot merely subscribe to the theory of transformation through moral images of freedom. Rather, it is through a frustrated thinking of change, one that recognises that transformation cannot happen through existing juridical institutions, that utopian thinking occurs. ${ }^{44}$ Whether or not that leads to change is not certain, but these are the conditions for utopian thinking, according to Jameson.

\section{Images of Utopia}

Both Cornell and Jameson deploy theories of symbolic projection in their competing theories of transformation. Cornell draws on Kant and Cassirer to contend that images of alternative possibilities have the power to grant us freedom to imagine otherwise, to think a different future and then realise it. Jameson argues that it is

43 Ibid., 54.

44 Jameson, The Political Unconscious, 288. 
not the fulfilled wish fantasies of such projections that stimulate change but, rather, their butting up against and subsequent revelation of a social and historical context and its attendant ideological trappings. As Kathi Weeks eloquently summarises, Jameson's 'signature contribution to utopian studies involves a shift in focus from the positive content of a utopian vision to its negative function of producing an estrangement from and neutralisation of the present order of things ${ }^{35}$ Certainly, for Jameson, it is still necessary to imagine change, but such visions cannot take on a positive, generalisable form - they must be keenly aware of the class composition and context under which they are imagined, for it is this that stifles transformation and this that must be understood and overcome for change to happen.

Up until now the focus of my engagement with the visual has largely relied on the use of image and imagination in these competing theories of transformation. But, without counteracting Cornell and Cassirer's insistence on the inherent relationship between symbolism and materialism, I want to briefly turn to some more concrete visual incarnations of Trump's project to 'make America great again. These cues cannot be disassociated from the popular rhetoric; these symbols are what instantiate the grip of the discourse on the collective imagination. They are necessary for the power of Trump and his claims. However, the anti-Trump camp has visual cues of its own. These

${ }^{45}$ Kathi Weeks "Utopian Therapy: Work, Nonwork, and the Political Imagination," in An American Utopia: Dual Power and the Universal Army, Slavoj Zizek, ed. 243-266. (London: Verso. 2016), 245. 
competing displays of visuality underscore my claim that both form and content are imperative to consider in theories of transformation, and that neither can be merely translated as universals, or reduced solely to their sociohistorical context.

One of the most prominent symbols of the Trump campaign and presidency is the red 'Make America Great Again' hat. This visual symbol, adorning the heads of Trump supporters across the United States, uses an all uppercase white embroidered declaration in what looks like Times New Roman font to communicate to those who witness it, in no uncertain terms, the 'America first' politics of the person whose head it sits on. ${ }^{46}$ Trump's own website features the hat, declaring that 'the hat became his symbol', along with a short video about the proud American workers that make them. ${ }^{47}$

This popular hat may be contrasted with another one, the counter-symbol to Trump's jingoistic chapeau: the pink knitted 'pussyhats' of the national Women's March that took place in Washington, DC in protest of Trump and his policies, on 21 January 2017, the day after his inauguration. Using the reclamation of production and colour popularly associated with women, marchers knitted, crocheted, and sewed pink hats (the patterns for

46 This was a slogan deployed by Trump on his inauguration day and has since found a home in the title of his approach to foreign affairs. For a full transcript of his speech from 20 January 2017 see Cao 2017. To read the "America First Foreign Policy" see. "America First Foreign Policy”, Accessed 25 April, 2017: https://www.whitehouse. gov/america-first-foreign-policy.

47 “Donald J. Trump”, Accessed 25 April, 2017m https://www.donaldj trump.com/2017. 
which were widely disseminated via the internet) that included two small ears to make the wearer resemble a cat or kitten. ${ }^{48}$ The cat theme was part of the marchers' claim that 'pussies grab back', a retort to the Fall 2016 scandal that revealed a previously audio-recorded conversation in which Trump boasted that he could grab women 'by the pussy' without their consent. ${ }^{49}$ But the central aim of the Pussyhat Project was to make 'a powerful visual statement' by having 'a sea of pink' descend on DC (Pussyhat Project). And indeed, this fuchsia-inspired visual reply to Trump's red snap-back was popularised in journalistic photos of the march, and appeared on the cover of Time Magazine as well as the New Yorker the following week..$^{50}$

It is imperative to consider Trump's red baseball cap in the context of Jameson's critique of universalism. With this visual symbol, Trump - like Cornell, Kant, and Rousseau - wants to pull on the positive imaginative possibilities of the electorate by encouraging them to imagine something better. While the slogan is the key part of this approach, it is given visual instantiation via the hat. A person wearing the hat tells others, not only what their individual politics are, but also that they are

${ }^{48}$ The knit pattern was originally designed by Kat Coyle, "Pussyhat Project", Accessed 25 April, 2017. https://www.pussyhatproject. com/faq/.

49 According to the Pussy Hat Project website, the hats are also about reclaiming the term as an empowering one: "We love the clever wordplay of 'pussyhat' and 'pussycat,' but yes, 'pussy' is also a derogatory term for female genitalia. We chose this loaded word for our project because we want to reclaim the term as a means of empowerment" (ibid.).

50 The hat was featured on the cover of Time Magazine on Thursday 26 January 2017 and the New Yorker on Friday 27 January 2017. 
part of a larger movement of hat-wearers. Furthermore, the hat embodies Trump's rhetoric of 'America first' as it proudly dons the stamp 'Made in the USA' on its reverse. The video on Trump's website works hard to embolden this narrative, showing labourers working happily in the hat-making factory, sharing their enthusiasm for Trump's fulfillment of his campaign promise to bring manual labour back to the USA.

And the Pussyhat is not dissimilar. Like the Trump hat, it too serves as a visual cue for observers; those who don the Pussyhat mark themselves as individuals with a particular politic, and as members of a group with a distinct political affiliation. While it does not use Times New Roman to communicate a central slogan, it too mobilises a visual aesthetic. Up and against the factory-made sheen of a generic baseball cap, the pink headwear communicates clear affinities to DIY, anti-corporate, grassroots and feminist principles. Indeed, the popular sharing of the knit pattern, which also allows for individual customisation, is part of the anti-centralisation politics of the Pussyhat Project: 'Part of the joy of the project is connecting to other women and men who support women's rights in a fresh surprising and warm way'. The Pussyhat Project sees their strategy as a caring, empathetic and collective, opposition to Trump-supporting Republicans. But aside from the content, the pink retort to Trump's red works similarly - in their fundamental form, both hats function as an image of universal appeal, with the aim of encapsulating an imagination (via a material symbol) that promotes and prompts transformation. Much like Rousseau's third estate, the hats act as a symbolic gesture to conjure 
up and expose a gap between what is and what ought to be, whether that be for the left or the right.

Further, Jameson reminds us that these symbols cannot be removed from their socio-historical context. For example, the red MAGA hat tells a formidable lie about the possibility of revitalising a manufacturing industry in contemporary America. Yet economists have emphasised that the decline in this sector of employment is not primarily the fault of international trade epitomised in the rally cries against the amorphous spectre of 'China', but rather automation. Jobs once held by workers in factories have been increasingly transferred to robots that can complete the work more quickly and for less expense to the employer. ${ }^{51}$ As these jobs have disappeared - at an incredible rate of approximately 5.5 million from 2000-2010 - similar paying jobs in other sectors have not opened up, leading to a rise in employment in the service sector industry, which is typically non-unionised and paid significantly less (Muro 2016). And perhaps most telling that this industry is not going to bounce back under Trump's 'America First' policies, is the fact that, during this time of great decrease in employment for the Rust Belt, American manufacturing has actually increased, becoming a more productive sector with a decreased and less expensive labour force..$^{52}$

And, the Pussyhat Project too may be in danger of forgetting its socio-historical conditions. Combining

51 Federica Cocco, "Most US manufacturing jobs lost to technology, not trade”. Financial Times (2 December 2016).

52 Mark Muro, "Manufacturing Jobs Aren't Coming Back”. Technology Review (18 Nov 2016). 
organisational forces with the National Women's March, the hats and the march sought to demonstrate a collective unity of resistance to the new Trump Administration, but also to catch the attention of representatives of Congress in order to steer their agendas towards social and environmental justice. ${ }^{53}$ Although the organising slogans of the approximately 500,000 marchers were clearly diverse, ranging from Indigenous sovereignty to anti-capitalism, the aim of the event mobilised the logic of that aim and correlates representation with democracy, part and parcel of the existing US political machinery. While organising around visibility and increased representation certainly has merit, the march has the danger of serving as a one-off event that sees its aim only as sending an anti-Trump message about personal freedoms for women. Even as Jodi Dean emphasises the power of the crowd to disrupt, she remarks: 'people must self-consciously assemble themselves in settings not determined by capital and the state $[\ldots]$ The challenge consists in changing political actions into political power. ${ }^{54}$ Organisers and participants may see the hats as symbols of hope and struggle, but, ultimately, the pink hats may function much like their myth-promoting rivals if they are not understood within their socio-historical context - a context that has seen the rise of a left increasingly oriented to fragmented individualism, with minimal attention to the sustained governmental attack on unions (a former force in

53 “Women's March". Accessed 25 April, 2017: https://www.womens march.com/.

54 Jodi Dean, Crowds and Party (New York: Verso 2016), 22. 
fighting for socio-economic change), as well as the axing of socio-economically-oriented programs such as affordable housing, healthcare, food, and other socially necessary subsidies, since the mid-1970s. ${ }^{55}$ As Jameson himself claims, even more sustained and organised movements like Occupy have emerged as a result of this failure of the left to combat these rollbacks, but this reality is oft forgot. ${ }^{56}$

Perhaps most importantly, however, both visual cues have failed to operationalise the kind of negative dialectic that Jameson claims is crucial for transformation. Although both hats embody - and arguably help foster frustration with the current political situation, this anger has been so far translated by optical managers into an endorsement of the existing capitalist democracy of the USA and its two-party system. If you are vexed at the loss of manufacturing in the nation and, as a result, feel threatened when you see immigrants and people of colour with jobs, turn your anger towards the representative candidate of the right - get a hat and vote for Trump. If you are shocked and dismayed at the popular acceptance of misogyny, racism, islamophobia, and climate change denying - as evidenced in the election of Donald Trump don your Pussyhat to show your repudiation of the new President. This is not to suggest that there is no political merit in marching, but that 'the task of utopianism today

55 Jefferson Cowie, Stayin' Alive: The 1970s and the Last Days of the Working Class (New York: The New York Press 2010), 68-74; Dean, Crowds and Party, 31-50; Rick Wolff, "Organized labor's decline in the US is well-known. But what drove it?". The Guardian (2 Sep 2013).

56 Fredric Jameson, An American Utopia: Dual Power and the Universal Army (London: Verso 2016), 42. 
[may be] rather to propose more elaborated versions of an alternate social system than simply to argue the need for one. ${ }^{57}$ Neither symbol forces an estrangement with the existing political-legal institutional reality via an exposure of the class composition of their context, which might allow for the ideological conditions of the present state of things to be exposed; instead, both rely on the Kantian-inspired deployment of the positive image and its role as a catalyst for transformation.

\section{A Return to Originalism}

As outlined in the introduction, what is interesting about originalism is not the presumed backwardness of its promoters, but rather the theory of transformation that lies behind it, which is also shared by liberal leftists who presume themselves radically distanced to such thinking. Indeed, both project future images of a better world in order to animate and organise their movements. I asked at the outset if the problem was the content of such imagery or in fact the very form. What I have attempted to show is that it is neither, or, rather, that it is both. Here Jameson's contention about the inseparability of ideology and utopia for both the left and the right gives important insight to understanding the commonly held theory of transformation between the two opposing camps. We can understand the call to 'make America great again' as one both steeped in a social and historical ideological context

57 Ibid., 43. 
of neo-liberalism that also deploys utopian thinking in amassing an imagined collective unity of disenfranchised citizens excluded from 'Washington', as the campaign rhetoric goes. But we can also analyse Cornell's 'moral images of freedom' as part and parcel of a liberal democratic philosophy that presumes the centrality of the individual subject and its powers of imagination and rationality that sit over and above any class-influenced position. Such symbolic projection pulls on hopeful imaginations of and for bourgeois freedom. In both theories, the ideological and utopian elements cannot be disentangled from each other. In addition, Jameson's focus on the negative potential of utopian thinking, up and against Cornell's holdout for the positive, tells us that both the content and the form of the theory of transformation must be considered in its context in order to reveal the ways in which this context shapes and moulds visions of what is possible.

Originalism postulates an immanent relationship with the Constitution. Somewhat similarly, the theory of legal transformation that Cornell relies on displays a belief in an immanent relationship between the self and its historical conditions; it presumes that there is no disjuncture between the two, that moral images of freedom can be accessed by the individual's imagination, unmediated by class-position or class-forces. In contrast, Jameson promotes the role of the transcendental in the necessary revelation between individual subject and the non-ideological reality of their social and historical conditions. Jameson's position corresponds with traditional anti-originalist thought that contends that all juridical reasoning must be 
keenly cognisant of context. My intention is not to say that one theory supersedes the other, but rather to point to the differing positions on the role of symbolic projection and utopian thinking in theories of transformation. As the Trump administration embarks on what is a very troubling path to restoring what conservatives imagine as America's lost greatness, it is important to remember that it is not necessarily merely the form or the content of the claims that require analysis - but both. It is not merely allusions to a great return or restoration that must put us on alert, but also the practice of symbolic projection itself. We must also understand that this isolationist and xenophobic rhetoric is not merely ideology, but also utopian in its thinking - the right, just as much as the left, can engage in exercises of imagining collective identity that fulfil these fantasies and encourage ideological adherence. Moreover, it is not only positive utopian thinking that may serve as a helpful tool in comprehending the situation we find ourselves in, but also - and perhaps especially - negative utopian thinking that reveals the limits of what is possible and what we imagine to be possible in the current moment.

\section{References}

Allison, Henry E. Kant's Theory of Taste: A Reading of the Critique of Judgment. Cambridge: Cambridge University Press, 2001.

Arendt, Hannah. Lectures on Kant's Political Philosophy. Chicago: University of Chicago Press, 1982.

Bennington, Geoff. 'Not Yet.' Diacritics 12 (1982): 23-32. 
Cao, Rachel. 'Read President Trump's full, blistering inaugural speech, attacking Washington, promising 'America first". CNBC. 20 January 2017. Accessed 25 April 2017: http://www. cnbc.com/2017/01/20/transcript-of-president-trumpsinauguration-speech.html.

Cocco, Federica. 'Most US manufacturing jobs lost to technology, not trade'. Financial Times. 2 December 2016. Accessed 25 April 2017: https://www.ft.com/content/dec677c0-b7e611e6-ba85-95d1533d9a62.

Cornell, Drucilla. Moral Images of Freedom: A Future for Critical Theory. New York: Rowman and Littlefield Publishers Inc, 2008.

Cowie, Jefferson. Stayin' Alive: The 1970s and the Last Days of the Working Class. New York: The New York Press, 2010.

Dean, Jodi. Crowds and Party. New York: Verso, 2016.

Flieger, Jerry Aline. 'The Prison-House of Ideology: Critic as Inmate. Diacritics 12. No 3. (1982): 47-56.

Jameson, Fredric, Leonard Green, Jonathan Culler and Richard Klein. 1982. 'Interview: Fredric Jameson'. Diacritics 12, no. 3 (1982): 72-91.

Jameson, Fredric. The Political Unconscious: Narrative as a Socially Symbolic Act. London: Routledge, 1981.

Jameson, Fredric. 'The Politics of Utopia'. New Left Review 25 (2004): January-February: 35-54.

Jameson, Fredric. An American Utopia: Dual Power and the Universal Army. London: Verso, 2016.

Kant, Immanuel. The Critique of Pure Reason. New York: Palgrave MacMillan, 2003.

Kant, Immanuel. The Critique of the Power of Judgment. Cambridge: Cambridge University Press, 2000.

Kauffman, Robert. 'Red Kant, or the Persistence of the Third 'Critique' in Adorno and Jameson'. Critical Inquiry 26, no.4 (2000): 682-724

Matherne, Samantha. 'Kant and the Art of Schematism'. Kantian Review 19, no. 2 (2014): 181-205. 
Mishra, Sabhajit. 'Kant's Schematism of Categories'. Indian Philosophical Quarterly 7, no. 4 (1980): 489-500.

Muro, Mark. Manufacturing Jobs Aren't Coming Back. Technology Review. 18 November (2016) Accessed 25 April 2017: https:// www.technologyreview.com/s/602869/manufacturing-jobsarent-coming-back/.

Nae, Cristian. 'Communicability and Empathy: Sensus Communis and the Idea of the Sublime in Dialogical Aesthetics', Proceedings of the European Society for Aesthetics 2 (2010): 361-385

Robinson, D. N. 'Just What is Kant's Project?' Lecture One on Kant's Critique of Pure Reason' (2011) Faculty of Philosophy, Oxford University. Accessed at http://www.philosophy.ox.ac. uk/podcasts/kants_critique_of_pure_reason.

Scalia, Antonin. 'God's Justice and Ours'. First Things: A Journal of Religion, Culture and Public Life, 123 (May) 2002: 17-21. Accessible at: https://www.firstthings.com/article/2002/05/ gods-justice-and-ours.

Ward, Ian. 'A Kantian (Re)Turn: Aesthetics, Postmodernism and Law'. Law and Critique 6 no. 2 (1995): 257-271.

Weeks, Kathi. 'Utopian Therapy: Work, Nonwork, and the Political Imagination'. In An American Utopia: Dual Power and the Universal Army, edited by Slavoj Zizek, 243-266. London: Verso, 2016.

White, Hayden. 'Getting Out of History'. Diacritics 12 no. 3 (1982): 2-13.

Wolff, Rick. 'Organized labor's decline in the US is well-known. But what drove it?'. The Guardian. 2 September (2013) Accessed 25 April 2017: https://www.theguardian.com/commentisfree/ 2013/sep/02/labor-unions-decline-can-turnaround. 